\title{
The Perspective of Social Work Education Development in Malaysia and Australia
}

Samir Muhazzab Amin, Tunku Latifah Tunku Ahmad, Mohd Suhaimi Mohammad, Norulhuda Sarnon@Kusenin, Ezarina Zakaria

To Link this Article: http://dx.doi.org/10.6007/IJARBSS/v11-i11/11657

DOI:10.6007/IJARBSS/v11-i11/11657

Received: 14 September 2021, Revised: 20 October 2021, Accepted: 30 October 2021

Published Online: 09 November 2021

In-Text Citation: (Amin et al., 2021)

To Cite this Article: Amin, S. M., Ahmad, T. L. T., Mohammad, M. S., Sarnon@Kusenin, N., \& Zakaria, E. (2021). The Perspective of Social Work Education Development in Malaysia and Australia. International Journal of Academic Research in Business and Social Sciences, 11(11), 1735-1752.

Copyright: (c) 2021 The Author(s)

Published by Human Resource Management Academic Research Society (www.hrmars.com)

This article is published under the Creative Commons Attribution (CC BY 4.0) license. Anyone may reproduce, distribute, translate and create derivative works of this article (for both commercial and non0-commercial purposes), subject to full attribution to the original publication and authors. The full terms of this license may be seen at: http://creativecommons.org/licences/by/4.0/legalcode

Vol. 11, No. 11, 2021, Pg. 1735 - 1752

Full Terms \& Conditions of access and use can be found at http://hrmars.com/index.php/pages/detail/publication-ethics 


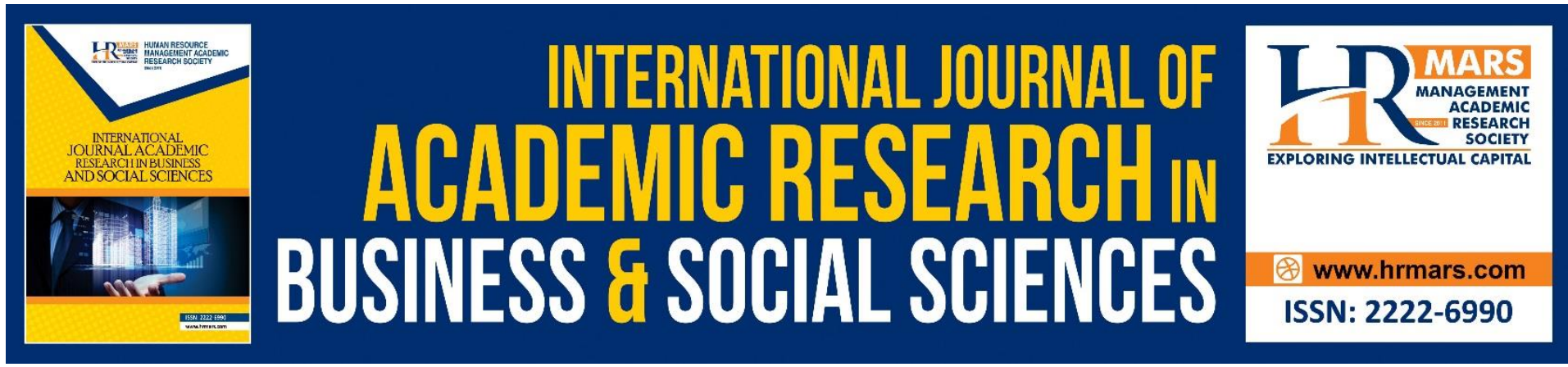

\title{
The Perspective of Social Work Education Development in Malaysia and Australia
}

\author{
Samir Muhazzab Amin, Tunku Latifah Tunku Ahmad \\ Department, of Social Science and Development, Faculty of Human Ecology, \\ Universiti Putra Malaysia, 43400 Serdang, Selangor. \\ Email: samir@upm.edu.my
}

\section{Mohd Suhaimi Mohammad, Norulhuda Sarnon@Kusenin, Ezarina Zakaria \\ Department of Psychology and Human Development, Faculty of Social Sciences and Humanities, Universiti Kebangsaan Malaysia, 43000 Bangi, Selangor.}

\begin{abstract}
This article explored the development of social work education in Malaysia and Australia focusing on three areas; professions, standards and education. The findings indicated that social work programmes and courses should be more entrepreneurial, research-oriented, and more efficient in its teaching methodology. Additionally, social work programmes should emphasise on the development of social work as a profession, strengthen the governance of social work education, and develop programs that focus on the global agenda. In Malaysia, the social work education began in 1975 whereas in Australia, it started in 1940 with the launch of Social Work Degree Program in the University of Sydney. In Australia, social work programmes are accredited by a professional body known as the Australian Association for Social Work (AASW), while in Malaysia, there is no established or authorised professional body to accredit the programmes. Without it, the path for social work profession to develop may be affected or compromised. This could be the contributing factor causing the delay in the development of social work education in Malaysia when compared to Australia.
\end{abstract}

Keywords: Social Work, Social Work Education, Education, Malaysia, Australia

\section{Introduction}

Social work is an academic field dealing with a wide range of human-environment interactions involving individuals, groups, and communities (Faruque \& Ahmmed, 2013). Social work education is a complex and challenging endeavour that necessitates enough resources, educators, clear procedures, and current curricula. Social work education programmes are influenced by economic and political situations, practise locations, population served, type of personal and social, economic, political, or environmental issues addressed, and practise theories and methodology used (International Federation of Social Workers, 2020) 
The field of social work in Malaysia begins with the formation of social welfare bodies to address social problems and issues, as it occurred in many other countries. Malaysia historically has been occupied by several colonial as well as outside powers including the Portuguese in early 1511, the Dutch in 1641, the English 1824, and the Japanese 1941-1945 (Hatta \& Saad, 2014). Regardless the occupations, there has been some form of welfare work in Malaysia for as long as people live in this country. The activities were carried out purely on the basis of human altruism, despite the fact that they had no formal training, job titles, or particular designations. There were no efficiency requirements in the system, it was just about helping those in need. As society continues to develop and becomes more complicated, new social issues emerge. Until recently, many Malaysians were unfamiliar with the term "social work" because the more familiar term used were welfare or volunteerism intertwined and frequently used interchangeably.

Professional social work was first introduced in Malaysia by the British Colonial Administration in the 1930s, but it was predominantly focused on the issues of migrant workers from India and China (Lee, 2011). According to Lee (2011) Department of Social Welfare was founded in 1946 after the World War II, when social problems like displacement, juvenile delinquency, and poverty became increasingly prominent. Financial aid for the underprivileged, juvenile delinquent probation programmes, women's and girls' protection homes, and residential care for the disabled and elderly were all implemented as social work services. After independence, the Department of Social Welfare has expanded its services to provide protection and rehabilitation to people, including the poor, natural disaster victims, children, elderly, disabled, and the homeless group. The Malaysian Association of Social Workers (MASW) was founded in 1973 when medical social workers sought to expand the organization's scope to encompass social welfare, prisons, and social work education. The purpose of this initiative was to strengthen professional competence in social work practise, education, and research in order to increase the efficiency and effectiveness of social services that will benefit the community's well-being.

In Malaysia, the development of social work education is strongly intertwined to the many welfare programmes and activities conducted by the government, non-profit organizations, and private agencies (Amin, Mohamad \& Tunku Ahmad, 2019). There are several ministries which directly linked to the social work services and profession which include the Ministry of Women, Family and Community Development, Ministry of Health, Ministry of Rural and Regional Development and Ministry of Higher Education. Almost all government and nongovernmental organisations in this country that provides service to the people offers social work services which indirectly creates employment opportunities for social workers. Among the services offered cover benefits and facilities which include protection for vulnerable children and young people, treatments and rehabilitation for offenders, ex-prisoners and drug users as well as support for the elderly and the disabled.

Indeed, the historical knowledge plays an important role in the development of social work identity. Social work research produces and contributes to knowledge about social work and human services, elucidates the nature of service users' life experiences, elaborate the ways in which inequality and diversity influence those experiences and advocates for social justice and inclusion (Shaw, 2007). In Australia, research for social work is classified according to a system which was developed by the Australian Bureau of Statistics for Australia. The system 
was designed to enable international comparisons for research statistics and to assist funding organisations and government departments in recording, categorising, scrutinising, and reporting on research activities in Australi (Australian Bureau of Statistics, 2008). The first national history of professional social work in Australia was researched by John Lawrence in the early 1960s, and published in 1965. Since then, only fragmented historical research has been conducted related to specific situations and problems, and many of these researches were performed by non-social workers who possessed diverse and sometimes unsympathetic attitudes towards social work and its' employees (Mendes, 2005).

This review is based on the results of research conducted in Malaysia and Australia, covering many aspects of social work research as disclosed in the journal and signifies good opportunity to analyse and compare social work education between Malaysia and Australia. The comparative review draws on the issues including profession, standards and education development.

\section{Study Purpose}

The purpose of this article is to expand our knowledge and provide a brief overview through advance empirical understandings on the perspective of social work education between Malaysia and Australia. Consistent with the existing research strategies, we conducted systematic literature review on these issues.

\section{Methods}

The researchers viewed the qualitative approach as a holistic picture in gathering extensive and detail information. This article is a systematic review on social work development between Malaysia and Australia. The review was conducted through vigorous search in which related research based on several characteristics including instituting social work that occurs within the development of social work in Malaysia and Australia. The process to look for these particular articles was sought from two main journal databases which are Scopus and Web of Science. The author identified keywords which include social work, profession, standards and education used for the search process. The outcome of the systematic review concurred that 16 articles are relevant and appropriate to be included and discussed for the current study (table, 1). 
Table 1: Selected Articles to Identify the Development of Social Work Education between Malaysia and Australia.

\begin{tabular}{|c|c|c|c|}
\hline $\begin{array}{c}\text { Title of Research } \\
\text { Article }\end{array}$ & Authors & $\begin{array}{c}\text { Development of Social Work } \\
\text { Practice }\end{array}$ & $\begin{array}{l}\text { Thematic } \\
\text { arises }\end{array}$ \\
\hline $\begin{array}{l}\text { Social work practice in } \\
\text { Malaysia: A vision of } \\
\text { direction }\end{array}$ & Ling (2002) & $\begin{array}{l}\text { The development of a } \\
\text { framework of social work } \\
\text { practices needs to be directed } \\
\text { towards the construction of } \\
\text { indigenous theories, and the } \\
\text { formulation of practical } \\
\text { approaches informed by local } \\
\text { methods to seek and provide } \\
\text { assistance. }\end{array}$ & $\begin{array}{l}\text { Practise, } \\
\text { challenge }\end{array}$ \\
\hline $\begin{array}{l}\text { Social work education } \\
\text { in Australia: at the } \\
\text { "crossroads" }\end{array}$ & $\begin{array}{l}\text { Camilleri } \\
(2005)\end{array}$ & $\begin{array}{l}\text { Social work programs are } \\
\text { expected to be more } \\
\text { entrepreneurial, } \\
\text { research oriented, and more } \\
\text { efficient in teaching } \\
\text { methodology. } \\
\text { methodology in social work } \\
\text { practice, students are also } \\
\text { expected to undertake broad } \\
\text { range of methods including } \\
\text { individual or casework, group } \\
\text { work, family work, } \\
\text { community work, social policy } \\
\text { development, management } \\
\text { and leadership, and research. }\end{array}$ & $\begin{array}{l}\text { Education, } \\
\text { impact, } \\
\text { opportunity }\end{array}$ \\
\hline $\begin{array}{l}\text { The history of social } \\
\text { work in Australia: A } \\
\text { critical literature } \\
\text { review }\end{array}$ & $\begin{array}{l}\text { Mendes } \\
(2005)\end{array}$ & $\begin{array}{l}\text { Historical knowledge will help } \\
\text { contribute to an accurate } \\
\text { assessment of contemporary } \\
\text { debates on education, } \\
\text { professional recognition, } \\
\text { social action, and other } \\
\text { practice and policy issues. } \\
\text { Social work interventions } \\
\text { have contributed to the } \\
\text { empowerment or social } \\
\text { control of welfare users. }\end{array}$ & $\begin{array}{l}\text { Issue, } \\
\text { opportunity, } \\
\text { practise }\end{array}$ \\
\hline $\begin{array}{l}\text { The working definition } \\
\text { of social work doesn't } \\
\text { work very well in China } \\
\text { and Malaysia }\end{array}$ & Fulcher (2013) & $\begin{array}{l}\text { The working definition of } \\
\text { social work used was builds } \\
\text { from the social } \\
\text { constructionist orientation. }\end{array}$ & Profession \\
\hline
\end{tabular}




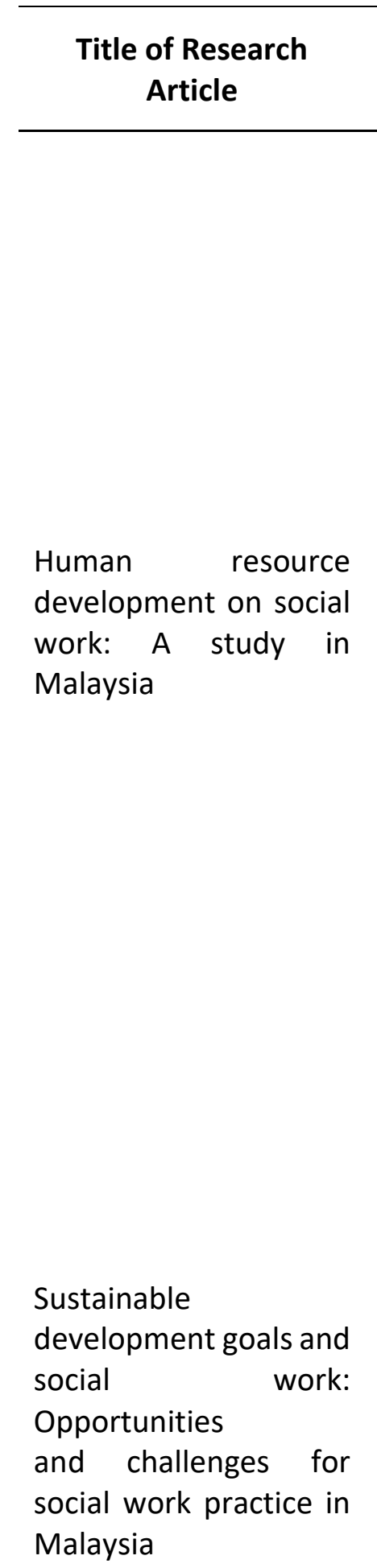

Jayasooria

(2016)

(2006)

Authors

Development of Social Work Practice

\section{Thematic \\ arises}

There are four comparative

themes that impact on a

working definition of social work including

communication and

conceptualization,

ethnography as the research method, dual legal system and cultural traditions.
The major issues and challenges to approach professional social work development are encouragement to improve the image of the social work profession, the need to develop integrated social work education and training opportunities, the importance of raising standards of professional social work practice and the need to solve employment dilemmas for social workers and create more employment opportunities.

The global social work community through proactive initiatives and documents on social work and social development facilitate positive social workers respond. Now, there is an opportunity as Malaysia is defining the framework for implementation.

A comparative study of Tilbury et al., (2017) According to social science disciplines, social work in Australia is a mid-level research Practise,

Profession, challenge

Profession, practise education 


\begin{tabular}{|c|c|c|c|}
\hline $\begin{array}{l}\text { Title of Research } \\
\text { Article }\end{array}$ & Authors & $\begin{array}{c}\text { Development of Social Work } \\
\text { Practice }\end{array}$ & $\begin{array}{l}\text { Thematic } \\
\text { arises }\end{array}$ \\
\hline $\begin{array}{l}\text { Impacts on the } \\
\text { implementation of } \\
\text { social policy: } \\
\text { Comparative study in } \\
\text { Malaysia and Indonesia }\end{array}$ & $\begin{array}{l}\text { Zainudin \& } \\
\text { Kamarudin } \\
\text { (2015) }\end{array}$ & $\begin{array}{l}\text { quantity and above average in } \\
\text { terms of quality. } \\
\text { The impact of social policy on } \\
\text { community development in } \\
\text { Malaysia and Indonesia has } \\
\text { been studied. Poverty } \\
\text { eradication programs must } \\
\text { help participants to achieve } \\
\text { their social and economic well } \\
\text {-being through } \\
\text { empowerment in social and } \\
\text { active investment } \\
\text { participation in economic } \\
\text { investment. }\end{array}$ & Policy \\
\hline $\begin{array}{l}\text { The relevance of global } \\
\text { standards to social } \\
\text { work education in } \\
\text { Australasia }\end{array}$ & $\begin{array}{l}\text { McNabb } \\
(2019)\end{array}$ & $\begin{array}{l}\text { The global standards show its } \\
\text { role in promoting quality } \\
\text { social work education at the } \\
\text { local level. One of implications } \\
\text { for social international work } \\
\text { education is including the } \\
\text { possibility of global role } \\
\text { standards in democratizing } \\
\text { social work education. }\end{array}$ & $\begin{array}{l}\text { Issue, } \\
\text { implication }\end{array}$ \\
\hline $\begin{array}{l}\text { Current development } \\
\text { of social work } \\
\text { education in Malaysia; } \\
\text { Views of its educators }\end{array}$ & $\begin{array}{c}\text { Zuraiju \& } \\
\text { Omar (2020) }\end{array}$ & $\begin{array}{l}\text { Most social work educators } \\
\text { give positive feedback on } \\
\text { development of social work } \\
\text { education where there is an } \\
\text { increase in number of public } \\
\text { universities offering social } \\
\text { work programs as well as the } \\
\text { number of social work } \\
\text { educators. }\end{array}$ & $\begin{array}{l}\text { Education, } \\
\text { profession }\end{array}$ \\
\hline $\begin{array}{l}\text { Starting the } \\
\text { indigenization process } \\
\text { of social work practice } \\
\text { in Malaysia }\end{array}$ & $\begin{array}{l}\text { Mohammed } \\
\text { et al., (2020) }\end{array}$ & $\begin{array}{l}\text { Social workers without formal } \\
\text { social work education are } \\
\text { common and out of ten social } \\
\text { workers with formal social } \\
\text { work education are formally } \\
\text { recruited for the role. Social } \\
\text { work requires a theory that } \\
\text { contains local culture }\end{array}$ & $\begin{array}{l}\text { Education, } \\
\text { challenge }\end{array}$ \\
\hline
\end{tabular}




\begin{tabular}{|c|c|c|c|}
\hline $\begin{array}{l}\text { Title of Research } \\
\text { Article }\end{array}$ & Authors & $\begin{array}{c}\text { Development of Social Work } \\
\text { Practice }\end{array}$ & $\begin{array}{c}\text { Thematic } \\
\text { arises }\end{array}$ \\
\hline & & $\begin{array}{l}\text { elements that can be used to } \\
\text { meet the needs of both } \\
\text { people and their } \\
\text { environments. There is a need } \\
\text { to observe certain specific } \\
\text { social, cultural and historical } \\
\text { factors. The nature of social } \\
\text { problems in Malaysia is } \\
\text { completely different from } \\
\text { proponents of current social } \\
\text { work theory and field } \\
\text { practices and roles for social } \\
\text { workers. The current } \\
\text { challenges of social work } \\
\text { environment in Malaysia } \\
\text { encompass the analysis of } \\
\text { social needs reduced to micro } \\
\text { levels at the individual and } \\
\text { family levels. }\end{array}$ & \\
\hline $\begin{array}{l}\text { Reconstructing and re- } \\
\text { conceptualizing social } \\
\text { work in the emerging } \\
\text { milieu }\end{array}$ & $\begin{array}{l}\text { Mcdonald \& } \\
\text { Jones (2000) }\end{array}$ & $\begin{array}{l}\text { New circumstances require a } \\
\text { reconstruction of Australian } \\
\text { social work at the level of } \\
\text { professional organization and } \\
\text { reconceptualization at the } \\
\text { level of practice theory. In the } \\
\text { case of social work, this } \\
\text { attribute collectively known } \\
\text { as 'practical theory', and is the } \\
\text { main method through which } \\
\text { professional project known as } \\
\text { 'social work' has been } \\
\text { structured, maintained, } \\
\text { projected and contested. }\end{array}$ & $\begin{array}{l}\text { Education, } \\
\text { profession }\end{array}$ \\
\hline $\begin{array}{l}\text { Professionalization of } \\
\text { social work in Malaysia } \\
\text { through } \\
\text { legislation: A literature } \\
\text { discussion on } \\
\text { concepts, } \\
\text { issues and challenges }\end{array}$ & $\begin{array}{l}\text { Hua \& Shafie } \\
\qquad(2017)\end{array}$ & $\begin{array}{l}\text { Malaysia needs to know its } \\
\text { strengths and limitations in to } \\
\text { address challenges in the } \\
\text { registration and licensing of } \\
\text { social workers. Four terms are } \\
\text { commonly used in reference } \\
\text { to regulatory system in social } \\
\text { work: credentialing, }\end{array}$ & $\begin{array}{l}\text { Profession, } \\
\text { legislation }\end{array}$ \\
\hline
\end{tabular}




\begin{tabular}{|c|c|c|c|}
\hline $\begin{array}{c}\text { Title of Research } \\
\text { Article }\end{array}$ & Authors & $\begin{array}{c}\text { Development of Social Work } \\
\text { Practice }\end{array}$ & $\begin{array}{c}\text { Thematic } \\
\text { arises }\end{array}$ \\
\hline $\begin{array}{l}\text { Proposed social } \\
\text { workers act gets the } \\
\text { government's nod. }\end{array}$ & $\begin{array}{l}\text { Scott \& Swain } \\
\quad(2002)\end{array}$ & $\begin{array}{l}\text { certification, registration and } \\
\text { licensure. } \\
\text { Malaysian government has } \\
\text { approved six measures to } \\
\text { enhance the social work } \\
\text { profession which includes the } \\
\text { establishment of the National } \\
\text { Social Work Competency } \\
\text { Standards, enacting Social } \\
\text { Workers Bill, establish a } \\
\text { national social work } \\
\text { regulatory body, recruitment } \\
\text { of qualified social workers, } \\
\text { standardization of education } \\
\text { and development of social } \\
\text { work courses at the certificate } \\
\text { and diploma levels }\end{array}$ & $\begin{array}{l}\text { Profession, } \\
\text { legislation }\end{array}$ \\
\hline $\begin{array}{l}\text { Development of social } \\
\text { work education and } \\
\text { practice in an era of } \\
\text { international } \\
\text { collaboration and } \\
\text { cooperation }\end{array}$ & $\begin{array}{c}\text { Farugue \& } \\
\text { Ahmmed } \\
(2013)\end{array}$ & $\begin{array}{l}\text { Approach to the international } \\
\text { social work profession should } \\
\text { be based on empirical } \\
\text { evidence and offer } \\
\text { constructive assistance in a } \\
\text { variety of social fields' } \\
\text { development solutions that } \\
\text { can be used for different } \\
\text { social needs. }\end{array}$ & $\begin{array}{c}\text { Profession, } \\
\text { challenge }\end{array}$ \\
\hline $\begin{array}{l}\text { Addressing } \\
\text { competency } \\
\text { requirement of social } \\
\text { work students during } \\
\text { the COVID-19 } \\
\text { pandemic in Malaysia }\end{array}$ & $\begin{array}{l}\text { Azman et. al } \\
\text { (2020) }\end{array}$ & $\begin{array}{l}\text { aims to provide an overview } \\
\text { of field education assessment } \\
\text { in Malaysia during the } \\
\text { pandemic and to pose } \\
\text { questions for future } \\
\text { assessment as Malaysian } \\
\text { social work drives towards } \\
\text { increased professional } \\
\text { regulation }\end{array}$ & $\begin{array}{l}\text { Practice, } \\
\text { regulation }\end{array}$ \\
\hline
\end{tabular}

\section{Analysis of Findings}

\section{Profession}

Social work is a helping profession. The principal goal of social work is to improve human wellbeing and assist individuals in meeting their basic and complex needs, with a specific focus on those who are vulnerable, oppressed, and poor. Understanding the relationship between 
human growth, behavior, social, economic, and cultural structures is central to social work. Even though social work initially began with informally helping others through welfare and voluntarism, it has now started to move towards making it as a professional function. The emphasis of social work around the world is to develop social work professional qualifications that will then address with contemporary social issues and problems in local and global communities. Internationally, it seems like many countries are heading towards registration of social workers aimed at raising standards and improving status of the profession (Beddoe \& Duke, 2009). According to the Malaysian Association of Social Workers (MASW), the issue of professionalism within the social work profession was first addressed in Malaysia in the 1930 s due to the growing problem which include substance abuse, mental illness and poverty. Few have noticed the process of professionalization in relation to the growth of social work in Malaysia from a legislative standpoint (Abdullah, 2003; Sinnasamny, 2006). MASW stated in 2004 that the social workers recruited by the Department of Social Welfare (JKM) and government hospitals receives training in the United Kingdom, Singapore, Australia, and Penang's University Science Malaysia (USM). This statement indicated that despite the rise in social problems, professional growth and development prospects in different fields of social work remain to be slow and limited.

In 2010, Malaysia's government endorsed six measures aimed at enhancing the social work profession which include (i) the establishment of National Social Work Competency Standards, (ii) the enactment of the Social Workers Bill, (iii) the establishment of a National Social Work Regulatory Body, (iv) the recruitment of qualified social workers, (iv) the standardization of education, and (vi) the development of social work courses at certificate and diploma levels (JKM, 2010). Additionally, four terms commonly used when referring to the social work regulatory system were included. They are (i) credentialing, (ii) certification, (iii) registration, and (iv) licensure or licensing. Among these four terms, credentialing is the most significant element to uplift a profession and is often used to refer to any document confirming a social worker's eligibility and competencies, and are typically used for voluntary recognition by professional associations (DeAngelis \& Monahan, 2012). This is due to the fact that once a social worker has met a certain set of criteria to do the job, he or she will be eligible to be credentialed, and the rest of the process toward professionalism will fall into place.

In Australia, social work profession was discovered since 1920's. Martin (1990) has studied and documented the history of social work in South Australia covering many profession issues including education, workforce, professional and gender issues. Crawford and Lietmann (2001) also studied the history of social work in Western Australia from 1920 to 1970, focusing on the impact of gender and class on early practitioners' training and their professional paths. Whereas Scott and Swain (2002) briefly described the role of social workers in Victoria Child Protection Association. Musgrove (2004); Peel (2004) on the other hand was found to document the early work practices of social workers in Victorian welfare services while, Peel (2003) reviewed the activities of social workers across the impoverished suburbs of Melbourne and Brisbane. All of the reviews and documentation did not provide any official history of social work in the area, but the description or testimony nevertheless provide some insights about the general picture of social and social work employees (good and bad) in less fortunate circumstances or neighborhood. However, the majority of important social welfare 
and policy literature in Australia make little or no mention to the evolution of the social work profession (Martin, 1990).

The approach to human rights highlighted by the Sustainable Development Goals (SDGs) is significant in identifying problems and regulating their implementation. It is regarded as important for the social work profession. According to Jayasooria (2016), the SDGs and social work values are synergistic, for instance, the Agenda 2030 draws attention to human dignity, inclusiveness, respect for diversity, equality and non-discrimination, empowerment, dependence, resilience, and self-help, as well as the ability to generate potential. These are the fundamental principles that have been recognized as required in social work practice. These principles are unquestionably essential to social work services and cannot be dissociated from the knowledge, skills, and competences needed to provide their services to human beings. However, it is unfortunately to know that this reality has not changed much for social work practitioners, who continue to see social services only as acts of care and compassion. When compared to other countries, particularly the developed nations, Malaysia's social work profession is still on the verge of being recognized as a profession.

Amin (2020) in his research stated that social workers without formal social work education is common. He asserted that the majority of practitioners recruited by Malaysia's Social Welfare Department to offer social work services to the people lacked formal social work education and were inadequately trained. As a result, this scenario will inevitably result in inefficiency. Abbot (1988) suggested that a profession must have a knowledge system that conforms to the task and a body that regulates the practice. In example, the medical or nursing professions are the best reference of professionalism in this country based on Abbot's description. When discussing the status of the social work profession in Malaysia at the moment, the route may be characterized as unclear, since there is no formal law regulating the activity or the people who offer it.

\section{Standard}

The primary mission of the social work profession is to enhance human well- being and help meet basic human needs of all people, with particular attention to the needs and empowerment of people who are vulnerable, oppressed, and living in poverty (NASW, 2020). Professional ethics are at the core of social work. The profession has a responsibility to articulate its basic values, ethical principles, and ethical standards. Sewpaul and Jones (2004) stated, the process of developing global standards for social work education and training is just as crucial as the final product, the established standards. In Australia, social work is a practice-based profession and academic discipline dedicated to promote societal change and development, social cohesiveness, and individual empowerment and liberation. Principles of social justice, human rights, collective responsibility and respect for diversities are central to social work. Underpinned by theories of social work, social sciences, humanities and indigenous knowledge, social work engages people and structures to address life challenges and enhance wellbeing. The Australian Social Work Education and Accreditation Standards (ASWEAS) set out the principles, standards, and graduate features for social work education in Australia. The standards serve as the criteria for the Australian Association of Social Workers to accredit a professional social work course (AASW) (ASWEAS, 2020). 
The ASWEAS graduate characteristics and learning goals are intended to guarantee that entrylevel social workers possess the fundamental knowledge, skills, and professional attitudes required for safe and ethical practice in all settings. The standards are used to determine if a professional social work programme is accredited by the Australian Association of Social Workers (AASW). The AASW provides standards for authorizing, evaluating, and monitoring programmes, while recognizing the responsibility of the higher education authority for course quality. When a university wishes to establish a social work programme, they may consult with an AASW consultant. The AASW recognizes its continuous obligation to ensure that graduates are equipped for this challenging environment. According to McNabb and Connolly (2019), standards in education are critical for improving students' quality and influencing the universality of social work education.

In Malaysia, social work education is also critical in ensuring the provision of high-quality social work practice, which is required for the development of effective and efficient social workers. A competent professional social worker must be able to operate in a variety of different kinds of social environments. According Azman et. al (2020), university-level social work education programmes in Malaysia were just recently established. In light of growing worldwide awareness and understanding regarding social work professionalism, it is critical for Malaysian social work education to have a standardized curriculum across institutions in order to create competent professional social workers with transferable knowledge and abilities. Improvements in social workers' knowledge and skills will ultimately benefit groups, families, and communities, supporting them in enhancing their social functioning. Hence, Malaysia's social work education committee agreed in principle that all institutions of higher learning providing social work programmes should design their curriculum in accordance with the professional standards and processes needed in the area of social work. Social work education should contain fundamental and necessary courses in social work, methodology, practical training, and supplemental courses that may help in understanding fields of social work. However, it is deemed to be quite difficult to standardize social work curriculum in Malaysia, since the country currently lacks a particular legislation or Social Work Act governing social work education.

The Social Work Act would further define and emphasize the true value of social work, as well as the ways in which it may be implemented to benefit the whole community (Amin et al., 2020). In addition, it would help to guide the roles of social work educators and practitioners in Malaysia. The National Joint Consultative Committee for Social Work Education (NJCCSWE) established in 2002 (Azman \& Abbas, 2012) aimed to strengthen the standards, competency, and direction of social work education in Malaysia. They emphasized the need of developing social work curriculums with curriculum, teaching, and learning methods that prepare students for general competency and professionalism. In terms of practicums, they should be performed and supervised properly, in accordance with good social work principles and practices. Although the importance of standardizing social work curriculum has been repeatedly emphasized, Malaysia only adheres to the minimal and general conditions set forth by the Malaysian Qualifications Agency (MQA), the Code of Practice for Programme Accreditation (COPPA), and the disciplinary Program Standards with which academic programmes must comply. 


\section{Education}

Social work began informally in Malaysia. Historically, charitable and welfare initiatives were more acknowledged by the community. The social work profession has evolved throughout time in response to the emergence of societal problems. Consequently, formal social work education has grown in need to meet the growing demand for social work services. The first social work training programme in Malaysia started before to independence, at the University of Malaya. The objective was to offer specialized training within social work education. (Jones, 1958). At the time, the social work training programme was incorporated into a diploma programme and referred to as the Diploma in Social Studies rather than the Diploma in Social Work. Following Malaysia's independence in 1957, University of Science Malaysia (USM) became the first university to offer social work education program at degree level in 1975 (Sinnasamy, 2006). The Social Work Program at USM was initiated by the Ministry of Social Welfare as a result of a UN Conference of Social Welfare. Ling (2002) stated that the establishment of academic programs for social work is one of the efforts to meet the needs to gradually provide rehabilitation to the poor societies, victims of natural disasters, protection and the rehabilitation of the children, elderly, disabled, homeless, young offenders, and young girls engaged in prostitution. From that, it will be then prompted and encouraged the appointment of more trained social workers. Although social work education has been established at the higher education level for more than 40 years, it is still lacking in terms of policies that might assist its growth toward professionalism.

In 2003, the Malaysian government launched the National Social Policy based on noble values aimed at enhancing human capacity to achieve social cohesion and stability, increase national resilience and improve the well-being of Malaysian society. The objectives outlined in this National Social Policy were seen to be the catalyst for the development of social work education in Malaysia. However, almost two decades after its inception, social work education in Malaysia continues to develop slowly. In fact, it fails to advocate for the passage of a social work act, which would confer legislative authority over the growth of social work services in general, including social work education. Even though Malaysia has not yet developed a social work act, the increasing need for social workers has prompted many institutions to offer social work degrees. The number of public universities offering academic programmes in social work has increased over time. At the present moment, there are seven universities that offered social work programs including Universiti Sains Malaysia (1975); Universiti Malaya (1992); Universiti Malaysia Sarawak (1993); Universiti Utara Malaysia (1997); Universiti Malaysia Sabah (2000); Universiti Kebangsaan Malaysia (2000); Universiti Sultan Zainal Abidin (2014). The social work programs offered in the public universities in Malaysia are listed in Table 2.

Social work education in Australia has a long history, dating all the way back to the late 1920s and early 1930s (Camilleri, 2005). However, social work education was not established at universities until 1940, with the University of Sydney being the first university to offer the course at the higher education level in the country. In Australia, social work education began on a solid foundation, since many of the country's early social workers received formal education from universities in the United States (Rosenman, 1980). To join the social work profession in the nation, candidates must hold a Bachelor of Social Work (BSW), a four-year degree programme. Additionally, many Australian universities offer a two-year accelerated graduate entry programme to the BSW for those with relevant experience in social work, 
welfare, or volunteerism. The Australian Association of Social Workers (AASW) recognises all of the courses and accepts its graduates as members. With its excellent standards for social work education, Australia has become a preferred destination for students from all over the globe seeking formal study in this profession.

Table 2: Social Work Academic Bachelor Programmes / Courses Offered by Malaysian's Universities

\begin{tabular}{ll}
\hline University & Name of Program \\
\hline Universiti Sains Malaysia (USM) & Bachelor of Social Work \\
\hline Universiti Malaya (UM) & Bachelor of Social Administration \\
\hline Universiti Malaysia Sarawak & $\begin{array}{l}\text { Bachelor of Social Sciences (Hons) } \\
\text { (UNIMAS) }\end{array}$ \\
\hline Social Work Studies \\
\hline Universiti Utara Malaysia (UUM) & Bachelor of Social Work \\
\hline Universiti Kebangsaan Malaysia & Bachelor of Social Work (Hons) \\
\hline Universiti Sultan Zainal Abidin & Bachelor of Social Sciences (Hons) \\
(Social Work)
\end{tabular}

Australia's social work education system is very similar to that of Malaysia. All are four-year or two-year undergraduate programmes that require students to have completed a social science degree or two-thirds of the degree. (Australian Association of Social Workers, 2020). While enrolled in a social work course, students are required to acquire fundamental knowledge in the areas of law and history, as well as the evolution of social policy, political institutions, indigenous problems, and the health system. Meanwhile, for methodology in social work practice, students are required to engage in and execute a variety of fieldwork including individual case study/casework, group work, family work, community work, social policy development, management and leadership, as well as research and evaluation (Camilleri, 2005). 
Table 3: Social Work Academic Bachelor Programmes / Courses Offered by Australian's Universities

\begin{tabular}{ll}
\hline \multicolumn{1}{c}{ University } & \multicolumn{1}{c}{ Name of Program } \\
\hline Australian Catholic University & Bachelor of Social Work (Hons) \\
\hline Charles Sturt University & Bachelor of Social Work (Hons) \\
\hline University of New England & Bachelor of Social Work \\
\hline University of New South Wales & Bachelor of Social Work (Hons) \\
\hline University of Newcastle & Bachelor of Social Work (Hons) \\
\hline University of Sydney & Bachelor of Social Work \\
\hline University of Wollongong & Bachelor of Social Work (Hons) \\
\hline Western Sydney University & Bachelor of Social Work \\
\hline Charles Darwin University & Bachelor of Social Work (Hons) \\
\hline Central Queensland University & Bachelor of Social Work \\
\hline Griffith University & Bachelor of Social Work (Hons) \\
\hline James Cook University & Bachelor of Social Work (Hons) \\
\hline Queensland University of Technology & Bachelor of Social Work (Hons) \\
\hline Southern Cross University & Bachelor of Social Work \\
\hline University of the Sunshine Coast & Bachelor of Social Work \\
\hline Flinders University & Bachelor of Social Work (Hons) \\
\hline University of South Australia & Bachelor of Social Work (Hons) \\
\hline University of Tasmania & Bachelor of Social Work (Hons) \\
\hline Deakin University & Bachelor of Social Work (Hons) \\
\hline La Trobe University & Bachelor of Social Work (Hons) \\
\hline RMIT University & Bachelor of Social Work (Hons) \\
\hline Victoria University & Bachelor of Social Work (Hons) \\
\hline Curtin University & Bachelor of Social Work (Hons) \\
\hline Edith Cowan University & Bachelor of Social Work (Hons) \\
\hline
\end{tabular}

As previously stated, social work education at universities is designed to fulfil the profession's requirements in assisting with the improvement of society's social functioning. When comparing Malaysia and Australia, it is clear that Australia places a greater focus on the significance of social work education and the professionalism of social workers as a profession. Further comparisons could be made using a variety of indicators, including population as a foundation. For instance, Australia, with a population of 25.6 million, has 24 universities (Table 3 ) that offer social work degree programmes, while Malaysia, with a population of 31.6 million, has only 7 universities that offer social work degree programmes. This demonstrates that the Australian government places a high emphasis on welfare services and quality, which falls in line with their vision to establish benchmarks for social work education and practise and to communicate effectively on issues of social justice, human rights, and issues affecting the overall quality of life for all Australians.

\section{Conclusion}

This article examined social work education in Malaysia and Australia in their effort to ensure that social workers and students have the required skills and knowledge to become effective social workers. Globally, social work education is critical to society's progress. Various international platforms have been established to enhance the theory, practise, and 
governance of social work. Today's economies are much more integrated and sensitive of social and political changes. The growth of social work education in Australia has been successful in raising the bar to a high level of excellence. Many countries have made Australia as a model for social work education including Malaysia. However, in order for social work education in Malaysia to thrive and stay relevant in delivering services to the community, it must undergo a major transformation to meet the issues and difficulties. To be effective, social work education must be adaptable to changing needs. Simultaneously, Malaysian social work education must implement educational reforms to guarantee that its curriculum standards are internationally recognized.

Thus, the government must try to actively execute the law, as this will contribute to the longterm development of education, professions, and social employment standards in Malaysia. Though we have significantly progressed in the development of social work education, there is still a lot of space for us the improve and learn from other countries. Moving ahead, Malaysian social work education may benefit from Australia's experience. As a profession, social work education in Malaysia must be certified by a recognized professional organization. Currently, MQA's general certification is inadequate to guarantee that Malaysian social work education is internationally recognised. Additionally, the Malaysian Associations of Social Workers (MASW) must take a more prominent role in protecting the practise and educational interests of social work. MASW should act similarly to the AASW, which is entrusted with advancing the profession of social work, promoting social justice, maintaining standards, and improving societal functioning.

\section{Acknowledgement}

We are thankful to our faculty members who provided insights and expertise that greatly assisted in the writing paper.

\section{Disclosure Statement}

No potential conflict of interest was reported by the authors.

\section{References}

AASW. (2000): Guidelines for determining eligibility of social workers. Canberra, Australia: Australian Association of Social Workers.

Abbott, A. D. (1988). The system of professions: An essay on the division of labour. University of Chicago Press.

Abdullah, M. B. (2003). Management of social work in Malaysia. Zakiyah Jamaluddin (Penyunting). Pengurusan perkhidmatan kerja sosial di Malaysia. Sintok: Penerbit Universiti Utara Malaysia.

Amin, S. M. (2020). Pembangunan pendidikan kerja sosial di Malaysia: Cabaran dan Keperluan (Unpublished doctoral dissertation). University Kebangsaan Malaysia, Bangi.

Amin, S. M., Mohamad, M. S., \& Ahmad, T. L. T. (2019). The development of social work undergraduate programs in Malaysia public universities: Issues, challenges and opportunities. Towards a Safer World: Addressing the Dynamics of Human Ecological Challenges, 45.

Amin, S. M., Mohamad, M. S., \& Azizul, M. D. A. (2020). Analisa Perspektif Kepentingan Akta Profesion Kerja Sosial di Malaysia: The Perspective of Significance of the Social Work Professionals Act in Malaysia. 'Abqari Journal, 23(1), 196-212. 
Azman, A., Jamir Singh, P. S., Parker, J., \& Crabtree, S. A. (2020). Addressing competency requirements of social work students during the covid-19 pandemic in Malaysia. The International Journal Social Work Education, 39(8), 1058-1065.

Beddoe, L., \& Duke, J. (2009). Registration in New Zealand social work: The challenge of change. International Social Work, 52(6), 785-797.

Camilleri, P.J. (2005). Social work education in Australia: at the" crossroads". Retrieved from https://ro.uow.edu.au/cgi/viewcontent.cgi?article=3085\&context=sspapers

Crawford, F., \& Leitmann, S. (2001), The shaping of West Australian social work, 1920-1970: The midwifery of power. Australian Social Work, 54(3), 43-54.

Faruque, C. J., \& Ahmmed, F. (2013). Development of social work education and practice in an era of international collaboration and cooperation. Journal of International Social Issues, 2(1), 61-70.

Harper, T. N., \& Harper, T. N. (2001). The end of empire and the making of Malaya. Cambridge University Press.

International Federation of Social Workers. (2020). Global standards for social work education and training. Retrieved from https://www.ifsw.org/global-standards-for-social-work-education-and-training/

Jayasooria, D. (2016). Sustainable development goals and social work: opportunities and challenges for social work practice in Malaysia. Journal of Human Rights and Social Work, 1(1), 19-29.

Jones, K. (1958). Social Welfare in Malaya. Donald Moove, Ltd.

Lee, P. N., \& NEO, L. (2011). Development of medical social work practice in Malaysia: A historical perspective (Doctoral dissertation, Master thesis). Universiti Sains Malaysia, Pulau Pinang, Malaysia).

Ling, H. K. (2002). Social work practice in Malaysia: A vision of direction. In Tan, N. T. \& Dodds, I. (Eds). Social work around the world (pp.82-102). International Federation of Social Work: Berne.

MASW. (2005) National Standards on Social Work Competencies for Malaysia: Department of Social Welfare, Kuala Lumpur.

Mendes, P. (2005). The history of social work in Australia: A critical literature review. Australian Social Work, 58(2), 121-131.

Mcdonald, C., \& Jones, A. (2000). Reconstructing and re-conceptualising social work in the emerging milieu. Australian Social Work, 53(3), 3-11.

McNabb, D. J., \& Connolly, M. (2019). The relevance of Global Standards to social work education in Australasia. International Social Work, 62(1), 35-47.

Mohammed, A. A., Uddin, M. S., \& Bougangue, B. (2020). starting the indigenisation process of social work practice in Malaysia. Social Work \& Society, 18(1), 1-14.

Musgrove, N. (2004). Filthy homes and fast women: Welfare agencies moral surveillance in post-second world war Melbourne. Journal of Australian Studies, 80, 111-119.

Onyx, J., \& Maclean, M. (1995). Career Progression in the Community Sector, Australian Journal of Social Issues, 30(1), 55-70.

Peel, M. (2003). The Lowest Rung: Voices of Australian Poverty. Cambridge University Press.

Peel, M. (2004). The imperfect bodies of the poor. Griffith Review, 4, 83-93.

Scott, D., \& Swain, S. (2002). Confronting Cruelty. Melbourne University Press.

Shaw, I. (2007). 'Is social work research distinctive?'. Social Work Education, 26(7), 659-69.

Sinnasamy, M. (2006). Human resource development on social work: A study of Malaysia. Working paper series, WP-2006-01-E. Nihon Fukushi University. 
Zubrzycki, J., Green, S., Jones, V., Stratton, K., Young, S., \& Bessarab, D. (2014). Getting it right: Creating partnerships for change. Integrating Aboriginal and Torres Strait Islander knowledges in social work education and practice: Teaching and Learning Framework. Sydney, NSW: Australian Government Office for Learning and Teaching.

Zuraiju, S. N. E. N., \& Omar, N. (2020). Current development of social work education in Malaysia: views of its educators. The Malaysian Journal of Social Administration, 14(1), 1-18. 